\title{
The Determinants of Capital Structure: EVIDENCE FROM COMPANIES LISTED ON THE WIG20 INDEX OF THE WARSAW STOCK OF EXCHANGE
}

\begin{abstract}
The paper investigates the relationship between capital structure and firm performance for the capital structure of listed companies in Poland. The main objective of this paper is to investigate which capital structure theories better describes the financing decisions in selected Polish companies traded on WIG20 index of the Warsaw Stock Exchange. The data come from consolidated financial statements audited of 14 companies of the WIG20.

\section{STRESZCZENIE}

W artykule przedstawiono zależność między strukturą kapitału a korporacyjnymi wynikami struktury kapitałowej spółek giełdowych w Polsce. Głównym celem tego opracowania jest zbadanie, które teorie struktury kapitałowej lepiej opisują decyzje finansowe w wybranych polskich spółkach notowanych na Giełdzie Papierów Wartościowych w Warszawie i należących do indeksu WIG20. Dane pochodzą z konsolidowanych sprawozdań finansowych audytowanych 14 firm z indeksu WIG20.

KEYwORDS: Capital structure, credit, equity, financial choice, polish listed companies, Pecking Order Hypothesis, Poland, trade-off

SŁOWA KLUCzOWE: Struktura kapitału, kredyt, kapitał, kompromis, wybór finansowy, polskie spółki giełdowe, Polska, teoria hierarchii źródeł finansowania
\end{abstract}




\section{OBjectives OF THE ARTICLE}

The aim of the article is to determine the capital structure which is used by selected polish listed companies on the Index WIG20 of the Warsaw Stock of Exchange (WSE). The structure of the paper is the following. In section 1, we review the considered literature, section 2 review data and methodology used by the author, findings are provided in section 3 . The aim of the article is to help financial analysts and managers to determine appropriate choices regarding capital structure matters which are relevant for the development of their considered companies.

\section{LiterATURE REVIEW}

Academic reflection on the choice and determinants of a company's financial structure has historically several approaches. Studies dedicated to Capital Structure are usually based on three financial theories. The traditional approach related to the transaction costs, the trade-off theory, and the pecking order framework. The theory is an important one while studying the Financial Economics concepts. It describes that the companies or firms are generally financed by both equities and debts.

The transaction costs theory was firstly developed by the British economist Ronald Coase. He considered "transaction costs" as a global framework for predicting when certain economic tasks would be performed by firms, and when they would be performed on the market. According to Hendriks (2011, p. 205) it's too costly to describe all relevant contingencies in any economic trade. There are three categories of transactions costs: Search and information costs to check whether a good is available on a market, bargaining costs related to make real an agreement, and Policing and enforcement costs related to the respect of a considered contract. This theory is explaining costs affected by companies regarding equity and debt emissions.

The trade-off theory of capital structure refers to the idea that an optimal capital structure exists for each company. It is the idea that a company chooses how much debt finance and how much equity finance to use by balancing the costs and benefits. Originated from the discussion issued by Modigliani and Miller (1958, p. 261-275), trade-off theory of capital structure basically entails offsetting the costs of debt against the benefits of 
debt. This hypothesis suggests that in making a choice among alternative forms of finance, organizations have a certain order of priorities. In the first instance, firms prefer to make use of internal finance generated by their operating cash flow. When these internal sources are used up, they prefer to borrow. The third option, which is used as a last resort, is the sale of new shares of the company (Pike and Neal, 2009, p. 32). The rationale for this preference order is the information asymmetry problem, i.e. the disparity between the information managers and potential investors have regarding the financial state of the firm and its future. Therefore, CFO are not fully optimistic regarding the emission of new shares which may be undervalued on a certain date, and more likely to issue them when it is believed that they are overvalued. Furthermore, The Trade-off theory of capital assumes no taxes and no bankruptcy costs which is clearly disputable regarding contemporary economy.

The Pecking Order Model developed by Myers (1984, p. 574-592) assumes that no optimal capital structure exists according to BiałekJaworska \& Nehrebecka (2015, p. 19). First the utilization of own sources should be preferred, and after use of external sources. According to this model firms prefer internal funding over external funding. Therefore, companies will tend to distribute lower dividends, using their retained earnings for financing capital expenditures. In case firms require external funding they would prefer debt over equity and equity is generated as last resort. So the firms don't have predetermined or optimum debt to equity ratio due to information asymmetry. The firms adopt conservative approach when it comes to dividends and use debt financing to maximize the value of company.

The trade-off theory contrasts the increase in bankruptcy costs with the tax advantage of debt. Indeed, the bankruptcy of an undertaking is none other than the judicial procedure which follows the default, it entails additional costs, these costs include explicit direct costs (legal costs of judicial administrations, liquidation) and implicit or Indirectly (loss of customers, loss of confidence of customers or suppliers). On an empirical level, among the main studies on bankruptcy costs, we cite the one carried out by Baxter (1967, p. 395-403), focusing on direct and more easily 
measurable costs, it estimates them at $20 \%$ of the value of firm. Other authors such as Gruber \& Warner (1977, p. 337-347) neglect bankruptcy costs and consider them too low to offset the tax benefit resulting from tax savings. De Angelo and Masulis (1980, p. 3-29) propose a model where there is an optimal level of indebtedness, they conclude that the marginal benefit of the debt is lower the lower the tax base by the other nonDeductible monetary assets. According to De Angelo and Masulis (1980), the optimal level of debt is due to the interactions between the various tax brackets induced by the different tax treatments of income from stocks and bonds. Meanwhile, the tax advantage of interest deductibility is a moderately important factor for Korean firms according to BiałekJaworska \& Nehrebecka (2015, p. 21).

There is also other emerging strand of literature that emphasizes the role of legal environment in firms' ability to raise external finance across countries. La Porta, Lopez-de-Silanes, Shleifer, and Vishney compare external finance across 49 countries based on English, French, German, or Scandinavian legal systems and find that the countries with better legal protection have more external financing available in both the debt and equity markets (LLSV, p. 1113-1155).

\section{DATA AND METHODOLOGY}

\section{Methodology}

In this article, the panel data analysis was used, in order to investigate the relationship between the choice of the structure of the capital and elements related to financial statements of selected polish companies of the WIG20 index. Due to specific balance sheets regulations, companies from the banking and insurance sectors were not taken in account in our sample. The WIG20 is a modified capitalization-weighted index of 20 Polish stocks which are listed on the main market of the WSE. The index is the underlying instrument for futures transactions listed on the WSE. The base value was set to 1000 as of April 16, 1994. As of the $26^{\text {th }}$ July 2017, its value is 2340 . Data related to solvability, liquidity, profitability were taken from consolidated and audited financial statements public listed companies previously mentioned and deeply analyzed. 4,424 is the exchange rate used for data coming from 
income statements (depreciation, EBITDA, profit, sales) is an average of the exchange rate PLN/EUR for 2016 available on the website of the Polish National Bank. 4,3634 is the exchange rate PLN/EUR as of the $31^{\text {st }}$ December 2016 used for data coming from Balance Sheets (Total assets, long and short-term debt) available on the website of the Polish National Bank. The 14 companies of the WIG20 index maybe classified in six industries. Orange (Telecommunications), Energa, JSW, KGHM, PGE, Lotos, PKN Orlen, Tauron, CCC, PGE (energy), CCC, Cyfrowy Polsat,Eurocash, and LPP (goods and services).

Table 1.

Descriptive statistics - debt relations

\begin{tabular}{|c|c|}
\hline Concept & Definition \\
\hline LTDDA & Long Term Debt / Total Assets \\
\hline LTDMC & Long Term Debt / Market Capitalization \\
\hline STDLTD & Short Term Debt / Long Term Debt \\
\hline TDTA & Total Debt / Total Assets \\
\hline
\end{tabular}

Table 2.

\section{Descriptive statistics - other relations}

\begin{tabular}{|c|c|}
\hline Concept & Definition \\
\hline CACTA & Cash and cash /Total Assets \\
\hline DTA & Depreciation/Total Assets \\
\hline ETA & EBIT/Total Assets \\
\hline FATA & Fixed Assets/Total Assets \\
\hline MVTA & Market Capitalization/Total Assets \\
\hline TPEBT & Tax Paid/Earning Before Taxes \\
\hline
\end{tabular}




\section{Data}

Data were collected from annual financial reports of selected companies listed on the WIG20 index. The total observed companies in this article are 14 companies excluding six companies from the financial and insurance sector. We used several measures of leverage. The first one is the Total Debt Ratio which consists of a division of total debt by total assets. The two following are the values of long-term and short term debt. The fourth one is the ration long-term debt divided by total debt, which usually consist of the largest portion of the debt to be repaid by companies. We took in account six other indicators which are not totally related to debt, but provide some crucial financial information concerning the structure of the 14 companies belonging to our sample. The dependent variable is the debt ratio; the explanatory variables include liquidity (cash and cash equivalents) non-debt tax shields (taxes), profitability (earnings before taxes), and tangibility (assets). For empirical reasons, all the variables are measured using book values because the data employed in this study come from financial statements only. This article provided the debt ratio as a measure of leverage, defined as book value of total debt divided by the book value of total assets. The total debt is the sum of short-term and longterm debt.

\section{ANALYSIS}

Table three provides basic financial data of companies of our sample. Table 3 and 4 give an analysis of the capital structure of companies. Table from 5 to 9 provide other statistical data used for our demonstration. Table 10 is a summary of acronyms used in the considered article.

The minimum debt ratio is $6 \%$ for Eurocash and $84 \%$ for two companies: Energa (Energy company) and Cyfrowy Polsat. The high debt ratio of Cyfrowy Polsat is due to several emissions of obligations, nevertheless a part of the long-term debt of Cyfrowy Polsat was reimbursed in mid-april 2017. Other companies such as JSW, Tauron, and PGE have also high debt ratio, respectively 73\%, 75\%, and 77\%. This set of figures implies that Polish listed companies relatively prefer using short-term debt over long-term debt. Regarding companies from the energy sector, due to important capital 
expenditures, companies prefer to emit shares which may prevent them from paying high interests due to potential loans. Nevertheless, it reduces automatically the tax benefits of financing by debt.

Polish companies prefer to use short-term debt versus long-term debt (table 6), the employment of short-term debt reduce the liquidity and the solvability of a company which must face with its short term obligations. It creates automatically an important financial risk which prevent these companies from getting a long-term loan. The table 9 shows the correlation between variables in the regression model. The ETA variable has a negative relationship with some of the variables of the capital structures. The MVTA variable has a strong correlation with the capital structure. Data provided in table 9 demonstrate the negative impact of profitability on leverage. In other terms it means that the utilization of debt financing shows a negative correlation with the company profitability.

Companies from the energy sector have usually a higher ratio of longterm debt to total debt than companies from the utility sector. This is due to the fact, that these firms have a high ratio of tangible assets which can be used as collaterals for loan taken. Companies from other sector where level of sales can quickly increase prefer to emit shares instead of taking loans, as the potential value of their equity is undervalued. Therefore, we can deduce, that these findings provide evidence that a considered industry have an impact over the concerned leverage and on the company's capital structure. Furthermore, companies should take in account that tax shield could be adjusted for inflation, which is expected to be increasing within the next years in Poland. According to Nha, Bich, and Nhung, the trade-off theory proposes that companies with higher profit should take more debt to protect their profits from income tax, whereas the pecking framework suggests to finance by themselves (2016, p. 36). Furthermore, according to Sheikh and Wang, due to a decreasing profitability of companies from the energy sector, tax shields benefit on the use of debt finance may either be reduced or even eliminated when a firm is reporting an income that is consistently low or negative, what happened to JSW during the fiscal year 2015, and KGHM in the fiscal year 2016 (2011, p. 122). Due to changing prices of raw materials, JSW is a leading producer of coal, accordingly to 
Bradley a firm's optimal debt level is a decreasing function of the volatility of its earnings. The higher volatility of earnings may indicate the greater probability of a firm being unable to meet its contractual claims as they come due. A firm's debt capacity may also decrease with an increase in its earnings volatility which suggests a negative association between earnings volatility and leverage (1984, p. 870). As noticed Vernimmen, the actual capital structure of a firm is necessarily a signal, but any change in it certainly is (2014, p. 661). This was also demonstrated by Ross, who consider that any change in financing policy changes investors' perception of the company and is therefore a market signal (1977, p. 34).

Many companies listed on the WIG20 are of an average size in comparison to western firms. Therefore, their turnover of assets is limited and automatically reduced their possibilities of taking a loan as having a lower degree of collateral, or no strong fixed assets than in the utility sector. Therefore, the value of assets of a company is positively correlated with the level of its long-term debt (LTDTA/TDTA).

The high proportion of short-term debt confirms the findings of Demirguc-Kunt and Maksimovic (1999, p. 295-336) that a major difference between developing and developed countries is that developing countries have substantially lower amounts of long-term debt (2011, p. 129).

The article also confirms findings of Sheikh \& Wang, that the variable size has a positive and significant impact on the debt ratio. This finding is consistent with the implications of the trade-off theory suggesting that larger firms should operate at high debt levels due to their ability to diversify the risk and to take the benefit of tax shields on interest payments (2011, p. 129). 


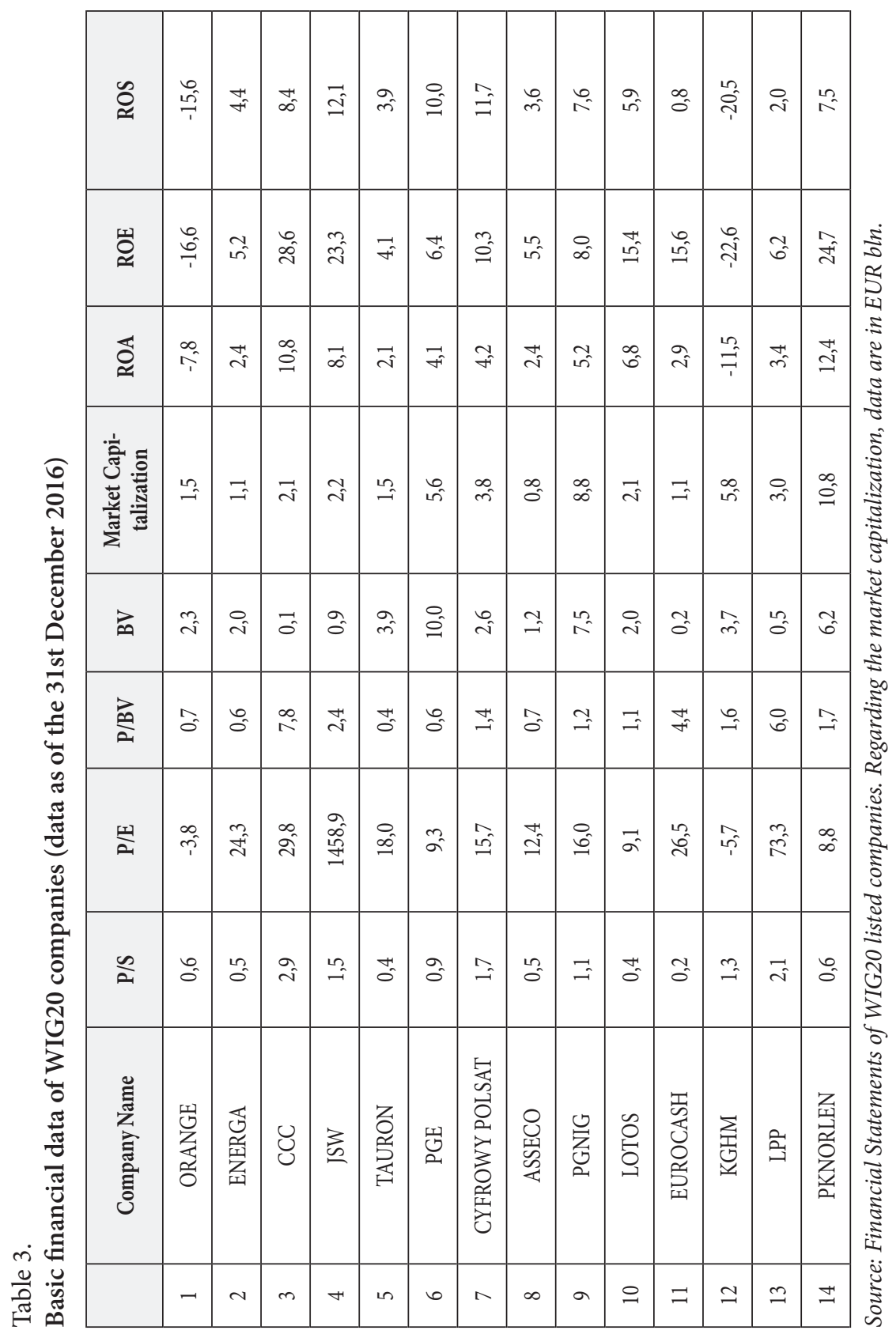




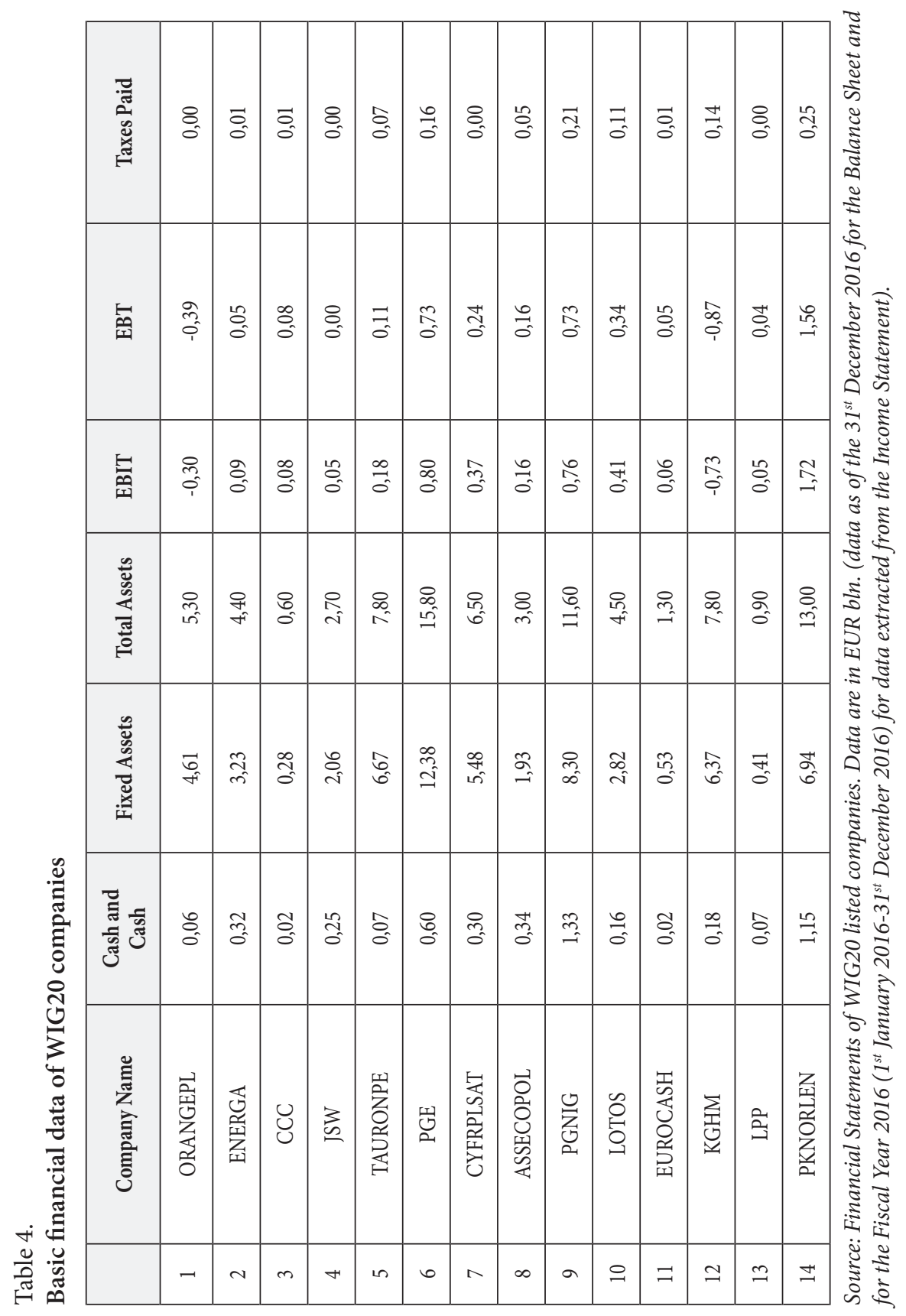


Table 5.

Debt structure of selected WIG20 companies (data as of the $31^{\text {st }}$ December 2016)

\begin{tabular}{|c|c|c|c|c|}
\hline & Company Name & TD & LTD & STD \\
\hline 1 & ORANGEPL & 2,8 & 1,6 & 1,2 \\
\hline 2 & ENERGA & 2,3 & 2,0 & 0,4 \\
\hline 3 & CCC & 0,5 & 0,2 & 0,3 \\
\hline 4 & ALIOR BANK & 0,0 & 0,0 & 0,0 \\
\hline 5 & JSW & 1,6 & 1,2 & 0,4 \\
\hline 6 & TAURONPE & 3,8 & 2,8 & 0,9 \\
\hline 7 & PGE & 5,2 & 4,0 & 1,2 \\
\hline 8 & CYFRPLSAT & 3,5 & 3,0 & 0,5 \\
\hline 9 & ASSECOPOL & 0,9 & 0,4 & 0,6 \\
\hline 10 & PGNIG & 3,5 & 1,7 & 1,8 \\
\hline 11 & LOTOS & 2,6 & 1,3 & 1,3 \\
\hline 12 & EUROCASH & 1,1 & 0,1 & 1,0 \\
\hline 13 & KGHM & 4,0 & 2,7 & 1,3 \\
\hline 14 & LPP & 0,4 & 0,1 & 0,3 \\
\hline
\end{tabular}

Source: Financial Statements of WIG20 listed companies. Data are in EUR bln.

Table 6.

Debt structure of selected WIG20 companies (data as of the $31^{\text {st }}$ December 2016) as a percentage

\begin{tabular}{|c|c|c|c|c|c|}
\hline & Company Name & TD/TA & LTD/TD & STD/LTD & LTD/MC \\
\hline $\mathbf{1}$ & $\mathbf{2}$ & $\mathbf{3}$ & $\mathbf{4}$ & $\mathbf{5}$ & $\mathbf{6}$ \\
\hline 1 & ORANGEPL & $53 \%$ & $57 \%$ & $76 \%$ & $106 \%$ \\
\hline 2 & ENERGA & $53 \%$ & $84 \%$ & $19 \%$ & $179 \%$ \\
\hline 3 & CCC & $82 \%$ & $31 \%$ & $223 \%$ & $7 \%$ \\
\hline 4 & JSW & $61 \%$ & $73 \%$ & $38 \%$ & $54 \%$ \\
\hline 5 & TAURONPE & $48 \%$ & $75 \%$ & $34 \%$ & $187 \%$ \\
\hline 6 & PGE & $33 \%$ & $77 \%$ & $29 \%$ & $71 \%$ \\
\hline 7 & CYFRPLSAT & $54 \%$ & $84 \%$ & $18 \%$ & $78 \%$ \\
\hline
\end{tabular}




\begin{tabular}{|c|c|c|c|c|c|}
\hline 1 & 2 & 3 & 4 & 5 & 6 \\
\hline 8 & ASSECOPOL & $31 \%$ & $41 \%$ & $146 \%$ & $48 \%$ \\
\hline 9 & PGNIG & $30 \%$ & $49 \%$ & $105 \%$ & $19 \%$ \\
\hline 10 & LOTOS & $57 \%$ & $49 \%$ & $104 \%$ & $60 \%$ \\
\hline 11 & EUROCASH & $82 \%$ & $6 \%$ & $1441 \%$ & $6 \%$ \\
\hline 12 & KGHM & $51 \%$ & $69 \%$ & $46 \%$ & $47 \%$ \\
\hline 13 & LPP & $41 \%$ & $18 \%$ & $462 \%$ & $2 \%$ \\
\hline 14 & PKNORLEN & $41 \%$ & $42 \%$ & $138 \%$ & $21 \%$ \\
\hline
\end{tabular}

Source: Financial Statements of WIG20 listed companies

Table 7.

Panel analysis of WIG20 companies (data as of the $31^{\text {st }}$ December 2016)

\begin{tabular}{|c|c|c|c|c|c|c|}
\hline & Company Name & CACTA & ETA & FATA & MVTA & TPEBT \\
\hline 1 & ORANGEPL & $1 \%$ & $-6 \%$ & $87 \%$ & $28 \%$ & $0 \%$ \\
\hline 2 & ENERGA & $7 \%$ & $2 \%$ & $73 \%$ & $25 \%$ & $25 \%$ \\
\hline 3 & CCC & $4 \%$ & $14 \%$ & $46 \%$ & $350 \%$ & $9 \%$ \\
\hline 4 & JSW & $9 \%$ & $2 \%$ & $76 \%$ & $81 \%$ & $79 \%$ \\
\hline 5 & TAURONPE & $1 \%$ & $2 \%$ & $86 \%$ & $19 \%$ & $60 \%$ \\
\hline 6 & PGE & $4 \%$ & $5 \%$ & $78 \%$ & $35 \%$ & $22 \%$ \\
\hline 7 & CYFRPLSAT & $5 \%$ & $6 \%$ & $84 \%$ & $58 \%$ & $1 \%$ \\
\hline 8 & ASSECOPOL & $11 \%$ & $5 \%$ & $64 \%$ & $27 \%$ & $29 \%$ \\
\hline 9 & PGNIG & $11 \%$ & $7 \%$ & $72 \%$ & $76 \%$ & $28 \%$ \\
\hline 10 & LOTOS & $4 \%$ & $9 \%$ & $63 \%$ & $47 \%$ & $33 \%$ \\
\hline 11 & EUROCASH & $2 \%$ & $5 \%$ & $41 \%$ & $85 \%$ & $17 \%$ \\
\hline 12 & KGHM & $2 \%$ & $-9 \%$ & $82 \%$ & $74 \%$ & $-16 \%$ \\
\hline 13 & LPP & $8 \%$ & $5 \%$ & $46 \%$ & $333 \%$ & $11 \%$ \\
\hline 14 & PKNORLEN & $9 \%$ & $13 \%$ & $53 \%$ & $83 \%$ & $16 \%$ \\
\hline
\end{tabular}

Source: own calculations 
Tables 8.

\section{Calculation of Descriptive statistics}

a) Dependent variables

\begin{tabular}{|c|c|c|}
\hline Concept & Median & Std. Dev. \\
\hline TDTA & $52 \%$ & 0,156 \\
\hline LTDTA & $27 \%$ & 0,132 \\
\hline STDLTD & $90 \%$ & 3,607 \\
\hline LTDMC & $51 \%$ & 0,569 \\
\hline
\end{tabular}

Source: own calculations

b) Characteristics of the companies

\begin{tabular}{|c|c|c|}
\hline Concept & Median & Std. Dev. \\
\hline CACTA & $4 \%$ & 0,036 \\
\hline ETA & $5 \%$ & 0,060 \\
\hline FATA & $72 \%$ & 0,154 \\
\hline MVTA & $66 \%$ & 1,035 \\
\hline TPEBT & $20 \%$ & 0,233 \\
\hline
\end{tabular}

Source: own calculations

Table 9.

Correlation among variables and panel regression results

\begin{tabular}{|c|c|c|c|c|c|c|c|c|c|}
\hline & TDTA & LTDTA & STDLTD & LTDMC & CACTA & ETA & FATA & MVTA & TPEBT \\
\hline TDTA & 1 & & & & & & & & \\
\hline LTDTA & 0,14 & 1 & & & & & & & \\
\hline STDLTD & 0,508 & $-0,630$ & 1 & & & & & & \\
\hline LTDMC & $-0,117$ & 0,666 & $-0,443$ & 1 & & & & & \\
\hline CACTA & $-0,220$ & $-0,220$ & $-0,308$ & $-0,308$ & 1 & & & & \\
\hline ETA & 0,100 & $-0,343$ & 0,125 & $-0,371$ & 0,337 & 1 & & & \\
\hline FATA & $-0,372$ & 0,726 & $-0,687$ & 0,6793 & $-0,1873$ & $-0,6242$ & 1 & & \\
\hline MVTA & 0,330 & $-0,352$ & 0,233 & $-0,5654$ & 0,0615 & 0,3910 & $-0,653$ & 1 & \\
\hline TPEBT & $-0,044$ & 0,199 & $-0,123$ & 0,2919 & 0,2841 & 0,1834 & 0,115 & $-0,234$ & 1 \\
\hline
\end{tabular}


Table 10.

Acronyms and ratio explanations

\begin{tabular}{|c|c|c|}
\hline Acronym & Explanation & Definition \\
\hline BV & Book Value & Total Assets minus liabilities \\
\hline LTD & Long Term Debt & $\begin{array}{c}\text { Amount owed for a period exceeding } \\
12 \text { months }\end{array}$ \\
\hline P/BV & Price to Book Value & $\begin{array}{c}\text { Current share price of a company relative } \\
\text { to its book value }\end{array}$ \\
\hline P/E & Price to Earning & $\begin{array}{c}\text { Current share price of a company relative } \\
\text { to its per-share earnings }\end{array}$ \\
\hline ROA & Return on Assets & $\begin{array}{c}\text { Division of a a company's annual earnings } \\
\text { by its total assets }\end{array}$ \\
\hline ROE & Return on Equity & $\begin{array}{c}\text { Division of a a company's annual earnings } \\
\text { by its total equity }\end{array}$ \\
\hline STD & Short Term Debt & Debt to be repaid within 12 months \\
\hline TA & Total Assets & Sum of assets of a company \\
\hline TD & Total Debt & Total debt of a company \\
\hline
\end{tabular}

\section{IMPLICATIONS AND LIMITATIONS}

Evidences from the article generally suggests the relevance of the pecking order hypothesis in explaining the financing choices of Polish firms. Companies have some preferences regarding their financing. First, the highest preference is to use internal financing (retained earnings and the effects of depreciation) before resorting to any form of external funds as they have a low level of fixed assets. Secondly, Polish companies rely on short-term debt either because of undeveloped bond market or due to high-cost long-term bank debt. Companies are using retained earnings for financing themselves and automatically reduce the level of dividends which maybe payed to shareholders. Instead of emitting new shares which maybe undervalued, companies prefer to take loans in spite of high credit costs in Poland in comparison to other European countries. 
It may be underlined, that better results would be achieved by applying more than 14 companies in our sample. Another solution would be to mention financial statements of a longer timeframe, in order to obtain better results. Therefore, the conclusion of this article shall be treated with caution. 6 more companies belonging to the WIG20 shall be considered in our analysis, but due to specific balance sheets regulations, companies from the banking and insurance sectors were not taken in account in our sample. In a other article, it may be suggested to enlarge the financial statements framework.

The article also emphasized that capital structure choice may be the result of a complex interaction of many institutional features and business practices that are not fully captured by differences in thelegal systems, which is especially important such as Poland where the legal system is quickly changing due to new politicians at the head of the state. All industry variable coefficients are statistically important and do confirm differences in capital structure among industries. This a topic which can be covered within a future article.

\section{References}

Angelo De, H., \& Masulis, R.W. (1980). Optimal capital structure under corporate and personal taxation, "Journal of Financial Economics", 8(1), p. 3-29. ISSN 0304405X.

Baxter, N.D. (1967). Leverage, risk of ruin and the cost of capital, "The Journal of Finance", 22(3), p. 395-403. ISSN: 1540-6261.

Białek-Jaworska, A., Nehrebecka, N. (2015). Determinants of Polish Companies'. Debt Financing Preferences, "Social Sciences", 87(1), p. 19-32. ISSN 1392-0758.

Bradley, M., Jarrel G., Kim, E.H. (1984). On the Existence of an Optimal Capital Structure: Theory and Evidence, "The Journal of Finance" 39(3), p. 857-880. ISSN: 15406261.

Demirguc-Kunt, A., Maksimovic, V. (1999). Institutions, financial markets and firm debt maturity, "Journal of Financial Economics", vol. 54, p. 295-336. ISSN 0304405X.

Dimitrios, V., Nikolaos, E., Nikolaos, D. (2009). Testing the Pecking Order Theory: The Importance of Methodology, "Qualitative Research in Financial Markets", 1(2), p. 85-96. ISSN 1755-4179

Gruber, M.J., Warner, J.B. (1977). Bankruptcy costs: Some evidence. “The Journal of Finance", 32(2), p. 337-347. ISSN: 1540-6261. 
Huang, G., Song, F.M. (2006). The Determinants of Capital Structure: Evidence from China. "China Economic Review", 17(1), p. 14-36. ISSN 1043-951X.

Jean, J. (2004). Determinants of Capital Structure of Chinese-Listed Companies, "Journal of Business Research", 57(12), p. 1341-1351. ISSN 0148-2963

Johnson, S. (1998). The Effect of Bank Debt on Optimal Capital Structure, "Financial Management", 27(1), p. 47-56. ISSN 1755-053X.

Marsh, P. (1982). The Choice between Equity and Debt: An Empirical Study, "The Journal of Finance", 37(1), p. 121-144. ISSN: 1540-6261.

Modigliani, F., Miller, M. (1958). The Cost of Capital, Corporation Finance and the Theory of Investment, "American Economic Review", 48(3), p. 261-275. ISSN $0002-$ 8282.

Myers, S.C. (1977). Determinants of Corporate Borrowing, "Journal of Financial Economics" 5(2), p. 147-175. ISSN 0304-405X.

Myers, S.C. (1984). The Capital Structure Puzzle, “The Journal of Finance”, 39(3), p. 574-592. ISSN: 1540-6261.

Nha, B.D., Bich Loan, N.T., Nhung, N.T.T. (2016). Determinants of capital structure choice: Empirical evidence from Vietnamese listed companies, "Society and Economy in Central and Eastern Europe", 38(1), p. 29-45. ISSN 1588-9726.

Porta, R.L., Lopez-de-Silanes, F., Shleifer, A., Vishny, R.W. (1998). Law and finance. "Journal of Political Economy", 106(6), p. 1113-1155. ISSN 0022-3808.

Pike, R., Neale, B. (2009). Corporate Finance and Investments - Decisions and Strategies, 6th Edition, Harlow: Prentice Hall. ISBN 9780273695615.

Ross, S. (1977). The determination of financial structure: the incentive-signalling approach. "The Bell Journal of Economics", 1977, p. 23-40. ISSN 0361-915X.

Sheikh, N., Wang, Z. (2011). Determinants of capital structure: An empirical study of firms in manufacturing industry of Pakistan, "Managerial Finance", 37(2), p. 117-133. ISSN 0307-4358.

Vernimmen P., Quiry P., Dallocchio M., Le Fur Y., Salvi A. (2014). Corporate Finance: Theory and Practice, Chichester: John Wiley \& Sons, Wiley.ISBN 9781118849330. 